\title{
STUDI LITERATUR TENTANG PENARAPAN SISTEM INFORMASI AKUNTANSI PENGGAJIAN UNTUK MENINGKATKAN KINERJA KEUANGAN
}

\author{
Eko Budi Suryan Syah'1, Siti Istikhoroh² \\ Universitas PGRI Adi Buana Surabaya1,2,3 \\ mbingmbing069@gmail.com
}

\begin{abstract}
ABSTRAK
Tujuan yang diusung pada penelitian ini adalah untuk memahami penggunaan sistem informasi akuntansi penggajian dalam peningkatan kinerja keuangan. Penelitian memakai pendekatan deskriptif kualitatif. Hasil yang didapatkan oleh peneliti dalam penelitian ini yaitu kinerja keuangan tidak terpengaruh secara langsung oleh sistem informasi akuntansi penggajian. Sistem informasi akuntansi penggajian juga tidak mempengaruhi profitabilitas, likuiditas, solvabilitas dan reliabilitas perusahaan yang menjadi penilaian kinerja keuangan perusahaan. Jadi pada karya tulis penelitian ini, simpulan yang diperoleh peneliti selama melaksanakan kegiatan penelitian adalah sistem informasi akuntansi penggajian tidak mempengaruhi kinerja keuangan secara langsung. Semoga penelitian ini berguna bagi peneliti selanjutnya sebagai bahan pertimbangan untuk mengembangkan penelitian ini dan menambah wawasan bagi para pembaca.

Kata kunci: sistem, akuntansi, penggajian, kinerja keuangan
\end{abstract}

\begin{abstract}
This research has a purpose to understand the applicability of the Payroll accounting information System in improving financial performance. This research uses qualitative descriptive methods. The results obtained by researchers in this study are that financial performance is not directly affected by the payroll accounting Information System. Payroll Accounting Information System also does not affect the profitability, liquidity, solvency and reliability of companies that become the company's financial performance assessment. So in the paper research, the conclusion that researchers acquired during the conduct of research activities is the information system of payroll accounting does not affect the financial performance directly. This research is expected to be useful for subsequent researchers as a consideration ingredient for developing this research and adding insight to the readers
\end{abstract}

Keyword: Systems, accounting, payroll, financial performance 


\section{PENDAHULUAN}

Sistem yang diterapkan pada sebuah perusahaan akan mempengaruhi perusahaan tersebut. Ada beberapa sistem yang diterapkan, salah satunya adalah sistem informasi akuntansi penggajian. Yang berfungsi mengatur jalannya pembagian hak yang didapat karyawan pada sebuah perusahaan.

Christina Kurnia Agatha dan Mulyadi (2018) dalam penelitiannya mengungkapkan bahwa penerapan sistem informaso akuntansi penggajian pada PT. Batik Arjuna Cemerlang Sukoharjo sudah berjalan baik namun masih ada beberapa fungsi yang belum baik, seperti rangkap tugas, sistem manual, dan belum memanfaatkan teknologi dalam pelaksanaan sistemnya. Eka Budi Yulianti (2018) hasil penelitiannya yaitu sistem akuntansi penggajian memiliki hubungan yang kuat dengan kepuasan karyawan. Dimita H. P. Purba (2018) juga menjelaskan hasil dalam penelitiannya bahwa penggunaan sistem informasi akuntansi penggajian dan pengupahan di rumah sakit telah efektif dan juga terkomputerisasi walupun belum online, namun masih ada ketidaksesuaian antara implementasi dengan prosedur yang ada.

Gita Gabriella Kakasih, Sifrid S. Pangemanan, dan Sherly Pinatik (2019) dalam penelitiannya kesimpulan yang didapat adalah pemakaian sistem akuntansi gajian karyawan pada Fakultas Ekonomi dan Bisnis Universitas Sam Ratulangi sudah diterapkan secara efektif jadi dapat mempermudah dalam pengambilan keputusan. Loli Saputri dan Yentina Siregar (2019) pada penelitiannya berpendapat bahwa sistem informasi penggajian yang diterapkan secara baik dan benar di PT. Cicor Panatek sudah sesuai dengan prosedur dan teori yang ada, termasuk data-data yang dipergunakan oleh PT. Cicor Panatek. Pada penelitian Mohammad Lunan Tajul Asrori, Taudlikhul Afkar, dan Sigit Prihanto Utomo (2019) hasil yang didapat yaitu sistem penggajian dan pengupahan pada PT Pembangunan Perumahan (Persero) Tbk belum berjalan dengan baik dan sistem otorisasi belum mendukung pengendalian intern yang berkaitan dengan penggajian dan pengupahan.

Zaki Baridwan (2013) menjelaskan bahwa system informasi akuntansi penggajian yaitu berupa form formulir, catatan, dan laporan gaji karyawan yang disusun untuk diberikan kepada manajemen guna mengelola perusahaan. Mulyadi (2016) juga menjelaskan laporan, catatan dan informasi pada pemakaian sistem gaji yaitu daftar gaji yang berubah, daftar pelaksanaan jam kerja masing-masing karyawan, kartu jam karyawan yang hadir tiap periode, catatan gaji dan upah, laporan gaji dan upah, surat yang menyatakan penghasilan masing-masing karyawan, amplop gaji, dan bukti kas keluar.

Perusahaan dapat dikatakan baik kalau kemampuan keuangan perusahaan tersebut bagus. Kinerja Keuangan adalah usaha dalam mengevaluasi aktivitas perusahaan pada periode tertentu (Harmono, 2014; 23). Munawir (2012) berpendapat tujuan dari penialian kemampuan keuangan untuk mengetahui kemampuan perusahaan pada tingkat likuiditas, solvabilitas, profitabilitas, dan stabilitas perusahaan. Dalam penilaian kinerja keuangan sebuah perusahaan, bagaimana penerapan sistem informasi akuntansi penggajian untuk meningkatan kinerja keuangan sebuah perusahaan? Maka dilakukan penelitian ini untuk mendapat penjelasan tentang penggunaan sistem informasi akuntansi penggajian dalam peningkatkan kinerja keuangan.

\section{ANALISIS PEMECAHAN MASALAH}


Penelitian ini berfokus pada pemecahan masalah tentang pemakaian sistem informasi akuntansi penggajian untuk meningkatkan kinerja keuangan. Penelitian ini menggunakan teori informasi akuntansi positif.

Watts dan Zimmerman (1986) mengutarakan pendapat tentang teori akuntansi positif bahwa praktik-praktik akuntansi untuk membuat prediksi dari peranan akuntansi serta informasi yang dipakai dalam membuat keputusan perseorangan, perusahaan, atau pihak yang terkait dalam merevaluasi aset.

Diharapkan pada penelitian kali ini, dapat membantu individu, perusahaan, dan pihak lain yang berpengaruh dalam menyampaikan keputusan tentang sistem penggajian yang dipergunakan dalam perusahaan. Kemudian dari pengambilan keputusan tersebut dapat membantu kinerja perusahaan, terutama pada kinerja keuangan.

\section{TINJAUAN PUSTAKA}

\section{Teori Akuntansi Positif (Positive Accounting Theory)}

Positive accounting theory atau teori akuntansi positif dicetuskan Watts dan Zimmerman (1986). Konsep ini mengutarakan penerapan akuntansi dan juga membuat proyeksi dari peranan akuntansi beserta informasi dalam menarik kesimpulan dari tiap pribadi, perusahaan dan juga kelompok yang lain. Penerapan teori ini akan menjelaskan maksud dan tujuan lembaga, organisasi, dan juga perusahaan dalam merevaluasi semua aset.

\section{Sisitem Informasi Akuntansi Penggajian}

Sistem akuntansi penggajian merupakan laporan, formulir, organisasi, dan juga catatan gaji karyawan yang diberikan pada setiap periode yang disusun untuk menyajikan informasi keuangan bagi manajemen untuk mempermudah pengelolaan masyarakat (Zaki Baridwan, 2013; 223). Mulyadi $(2016$; 310) menjelaskan laporan, catatan dan informasi yang diperlukan pada sistem informasi akuntansi penggajian yaitu daftar gaji yang berubah, daftar pelaksanaan jam kerja masing-masing karyawan, kartu jam karyawan yang hadir tiap periode, catatan gaji dan upah, laporan gaji dan upah, surat yang menyatakan penghasilan masing-masing karyawan, amplop gaji, dan bukti kas keluar.

Dokumen-dokumen yang dipakai dalam sistem gaji menurut Mulyadi (2016; 317) yaitu dokumen harga produk, jurnal umum, daftar biaya, dan dokumen gaji pegawai. Fungsi-fungsi yang ada pada sistem gaji menurut Mulyadi (2016; 317) yakni ketenagakerjaan, catatan tiap periode, pencatat gaji dan upah, akuntan, dan juga keuangan.

\section{Kinerja Keuangan}

Kinerja keuangan adalah usaha perusahaan untuk melakukan penialaian efektivitas dan efisiensi aktivitas perusahaan selama periode tertentu (Harmono, 2014).

\section{Tujuan kinerja keuangan}


Munawir (2012) menyampaikan, penilaian kinerja keuangan adalah memberi informasi tingkat likuiditas, profitabilitas, solvabilitas dan stabilitas sebuah perusahaan.

\section{Manfaat Kinerja Keuangan}

Penilaian kinerja keuangan menurut Sujarweni (2017), akan menginformasikan prestasi yang didapat perusahaan, menilai pencapaian per departemen, dasar penentuan strategi perusahaan, menunjukkan informasi dalam membuat keputusan, dan dasar penentuan kebijakan penanaman modal.

Fokus karya ilmiah ini pada penerapan sistem informasi akuntansi penggajian dalam peningkatan kinerja keuangan. Maka fokus pada penelitian ini yaitu.

1. Sistem informasi akuntansi penggajian. Hal-hal yang diperhatikan pada sistem informasi akuntansi penggajian yakni, dokumen yang dipergunakan, catatan yang diperlukan, fungsifungsi yang dijalankan, dan sistem yang dibentuk oleh jaringan-jaringan prosedur

2. Kinerja keuangan. Hal-hal yang dinilai pada kinerja keuangan yakni mengetahui tingkat kemampuan likuididtas, solvabilitas, profitabilitas, dan stabilitas sebuah perusahaan.

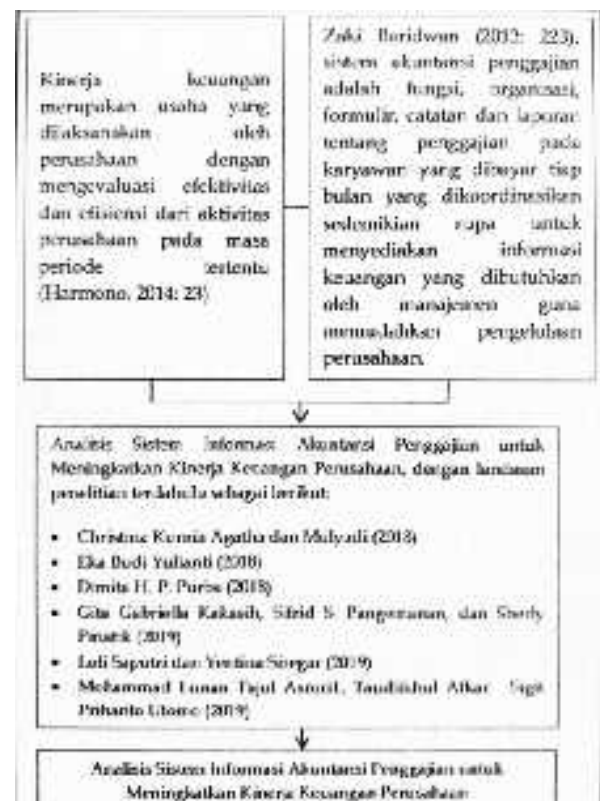

Gambar 1. Kerangka Konseptual

\section{METODE}

Penelitian ini akan memakai jenis penelitian deskriptif dengan metode kualitatif. Studi pustaka/kajian literatur terdahulu yang akan menjadi data pada penelitian ini. Teknik yang digunakan pada penelitian ini adalah mengumpulkan dan mendokumentasikan penelitian yang sudah ada yang sesuai dengan fokus penelitian.

Teknik analisa data yang telah diperoleh pada penelitian ini yaitu dengan menganalisa data-data (studi kasus) dengan teori-teori yang relevan. Setelah dilakukan analisis, maka kesimpulan dapat ditarik dari analisa studi kasus dengan teori-teori relevan yang dipergunakan.

Langkah-langkah yang digunakan pada analisis data yaitu 
1. Pertama, mengumpullkan studi kasus (penelitian terdahulu) yang berkaitan dengan penelitian ini.

2. Kedua, melakukan proses klasifikasi untuk mendapat data yang diperlukan.

3. Ketiga, melakukan perbandingan dan analisa pada kajian pustaka dengan teori-teori yang dipakai.

4. Keempat, mendeskripsikan dan menarik kesimpulan dan saran dari penelitian ini

HASIL

ANALISIS DATA

Analisis Sistem Informasi Akuntansi Atas Penggajian Dan Pengupahan Pada PT. Batik Arjuna Cemerlang Sukoharjo

Penelitian ini dilakukan oleh Christina Kurnia Agatha dan Mulyadi (2018). Hasil pada penelitian ini yaitu sistem di PT. Batik Arjuna Cemerlang Sukoharjo sudah dilaksanakan dengan baik sesuai Sistem Pengendalian Intern, namun ada beberapa bagian dari sistem yang belum diterapkan, yaitu masih ada tugas ganda pada masing-masing karyawan, sistem manual, dan belum terkomputerisasi.

Pengaruh Sistem Akuntansi Penggajian dan Pengupahan Terhadap Kepuasan Karyawan Pada PT. Tri Chemindo Ampuh

Penelitian ini dilakukan oleh Eka Budi Yulianti (2018). Pada penelitian ini, hasil yang didapatkan adalah hubungan yang semakin kuat antara Sistem Akuntansi Penggajian dan Pengupahan terhadap Kepuasan Karyawan. Hal tersebut terbukti dari nilai $\mathrm{R}$ yang menunjukkan angka 0,871 dibawah nilai intervalnya yaitu 1 . Kemudian pada uji t menyatakan hasil bahwa Sistem Akuntansi Penggajian dan Pengupahan berpengaruh secara signifikan terhadap Kepuasan Karyawan.

\section{Analisis Kinerja Keuangan Pemerintah Daerah Kabupaten Tapanuli Tengah}

Penelitian ini dilakukan oleh Heri Faisal Harahap (2020). Hasil yang didapatkan oleh penelitian ini adalah kemampuan keuangan Pemerintah Daerah Kabupaten Tapanuli Tengah bisa dikatakan cukup baik, walaupun rasio derajat desentralisasi masih tergolong rendah, ketergantungan Pemerintah Pusat/Provinsi masih sangat tinggi serta penerimaan PAD tidak mencapai target yang dianggarkan.

Faktor-Faktor Yang Mempengaruhi Profitabilitas Perbankan (Studi Kasus pada Bank Umum yang Terdaftar di Bursa Efek Indonesia Periode 2015 -2017

Penelitian ini dilakukan oleh Nyimas Vila Dewi (2019). Hasil dari penelitian ini yaitu secara tidak langsung Capital Adequacy Ratio melalui permasalahan kredit mempengaruhi pengembalian ekuitas perusahaan secara signifikan. Pada penelitian ini juga menunjukkkan, batas bunga bersih melalui permasalahan kredit tidak berpengaruh nyata pada pengembalian ekuitas perusahaan, rasio peminjaman pada deposito melalui permasalahan kredit berpengaruh nyata terhadap pengembalian ekuitas perusahaan. Beban Operasional terhadap Pendapatan Operasonal melalui permasalahan kredit berpengaruh nyata terhadap pengembalian ekuitas perusahaan.

Evaluasi Faktor-Faktor Yang Mempengaruhi Profitabilitas pada Perusahaan Manufaktur yang Terdaftar di BEI 
Penelitian ini dilakukan oleh Rina Dwiarti (2019). Penelitian ini menunjukkan pada tahun 2010, rasio perputaran total asset mempengaruhi pengembalian ekuitas perusahaan secara baik, sedangkan empat variabel lainnya yang yaitu pengembalian ekuitas perusahaan tidak terpengaruh secara nyata oleh rasio lancar, rasio perbandingan hutang terhadap ekuitas, persediaan yang terjual pada periode tertentu, dan rasio penghasilan harga.

Pengujian juga dilakukan pada tahun 2011, Rasio perputaran total asset secara nyata dan positif mempengaruhi pengembalian ekuitas perusahaan, dilain hal pada empat penilaian yang lain: pengembalian ekuitas perusahaan tidak terpengaruh secara nyata oleh rasio lancar, rasio perbandingan hutang terhadap ekuitas, persediaan yang terjual pada periode tertentu, dan rasio penghasilan harga.

\section{Analisis Faktor-Faktor yang Mempengaruhi Likuiditas Perbankan di Indonesia}

Arif L. Santoso dan Tekad Sukihanjani (2012) menjelaskan hasil dari penelitian ini yaitu faktor nilai standar sebuah bank tidak mempengaruhi kemampuan memenuhi kewajiban perbankan dalam jangka pendeknya, tapi tak terlihat nyata. Namun berpengaruh pada NPL tetapi tidak berpengaruh secara relevan pada kemapuan bank dalam memenuhi kewajiban jangka pendek.

Modal kerja bersih, kemampuan mendapatkan laba, dan rasio kecukupan modal berpengaruh secara baik dan relevan pada kemampuan perbankan dalam memenuhi kewajiban. Kemampuan pengembalian ekuitas pada perbankan berpengaruh buruk dan nyata terhadap pemenuhan kewajiban jangka pendek bank. Pada imbal jasa deposito tidak baik pengaruhnya dan nyata terhadap kemampuan memenuhi kewajiban jangka pendek suatu bank.

\section{Analisa Variabel yang Mempengaruhi Likuiditas Pada Industri Ritel yang Terdaftar Pada Bursa Efek Indonesia Tahun 2007-2012}

Penelitian ini dilakukan oleh Lisa P. Sugiono dan Y. Jogi Christiawan (2012). Hasil yang didapatkan oleh peneliti dalam penelitian ini yaitu besar kecilnya perusahaan mempengaruhi perusahaan tersebut. Tapi, besar kecilnya perusahaan mempengaruhi kemampuan pemenuhan kewajiban jangka pendek perusahaan. Artinya perusahaan besar bisa jadi mempunyai hutang lebih besar dari perusahaan biasa walau pembiayaan secara eksternal perusahaan besar lebih kecil.

\section{Profitabilitas, Solvabilitas dan Audit Delay pada Perusahaan Consumer Goods yang Terdaftar di BEI}

Bahtiar Efendi (2018), selaku peneliti dalam penelitian ini menjelaskan bahwa audit drelay tidak akan terpengaruh pada besarnya profitabilitas perusahaan. Karena tingkat kemampuan mendapat laba yang dinilai rendah akan menimbulkan kemunduran penerbitan catatan keuangan perusahaan, dan mengeluarkan informasi kerugian. Kemudian, memohon tim penguji data memanajemen waktu pengujian datanya. Tingginya perhitungan kemampuan perusahaan dalam memenuhi semua kewajiban mengakibatkan waktu penyelesaian lebih lama. Selain itu, faktor lain yang mempengaruhi adalah kurangnya penegakkan peraturan kesepakatan utang di Indonesia dalam melampirkan informasi pengujian data sesuai dengan publikasinya.

\section{PEMBAHASAN}

Hasil sintesa dari pengumpulan data kajian literatur dan teori-teori relevan yang dipergunakan, maka hasil yang didapatkan adalah sistem infromasi akuntansi penggajian tidak 
memberikan dampak secara langsung pada kinerja keuangan. Pernyataan tersebut didukung oleh penelitian Christina Kurnia Agatha dan Mulyadi pada tahun 2019 yang menyimpulkan bahwa sistem informasi akuntansi penggajian hanya bersinggungan dengan sistem, dokumen, serta fasilitas yang dipergunakan untuk menilai baik buruknya suatu sistem yang dijalankan. Dan pada penelitian Dwi Ayu Lestari, dkk yang dilakukan pada tahun 2020 yang menyatakan bahwa kinerja keuangan sebuah organisasi, perusahaan, dan lembaga dikatakan baik apabila efisiensi dan efektivitas keuangan perusahaan dapat berjalan stabil dan seimbang.

\section{SIMPULAN}

Penelitian berfokus pada penerapan sistem informasi akuntansi penggajian untuk meningkatkan kinerja keuangan dengan memakai teori akuntansi positif yang diharap mendapatkan hasil yakni dari penelitian bisa membantu pihak yang terkait terutama pihak manajemen sebuah organisasi, perusahaan, dan lembaga dalam pengambilan keputusan tentang sistem informasi akuntansi penggajian untuk meningkatkan kinerja keuangan. Namun, setelah dilakukan analisis dan sintesa pada kajian pustaka memakai teori-teori yang baik dan benar sesuai dengan penelitian, simpulan penelitian ini yaitu sistem informasi akuntansi penggajian tidak mempengaruhi kinerja keuangan secara langsung. Karena pada sistem informasi akuntansi penggajian, faktor-faktor yang mempengaruhi pada sistem yakni sistem, dokumen, dan fasilitas yang dipergunakan pada saat menjalankan sistem. Dan pada kinerja keuangan dapat dinyatakan stabil apabila efektivitas dan efisiensi keuangan berjalan baik dan berimbang, baik pada kewajiban profitabilitas, likuiditas, solvabilitas, dan stabilitas menjalankan perusahaan.

\section{IMPLIKASI}

Penelitian ini dapat memberikan pengetahuan mengenai faktor-faktor sistem informasi akuntansi penggajian dan penilaian kinerja keuangan perusahaan. Dan memberikan pengetahuan dalam penerapan sistem informasi akuntansi penggajian dalam meningkatkan kinerja keuangan.

\section{KETERBATASAN PENELITIAN}

Keterbatasan yang dihadapi oleh peneliti dalam menjalankan penelitian ini yaitu kurangnya informasi yang diharapkan peneliti dalam pelaksanaan penelitian.

\section{DAFTAR PUSTAKA}

Agatha, Christina Kurnia; Mulyadi. 2018. Analisis Sistem Informasi Akuntansi Atas Penggajian Dan Pengupahan Pada PT. Batik Arjuna Cemerlang Sukoharjo. Advance. Volume 5, Nomor 2, ISSN:2337-1375. STIE Adi Unggul Bhirawa Surakarta.

Asrori, Mohammad Lunan Tajul, Taudlikhul Afkar, dan Sigit Prihanto Utomo. 2019. Analisis Penerapan Sistem Akuntansi Penggajian Dan Pengupahan Pada Karyawan Dalam Upaya Mendukung Pengendalian Intern (Studi Kasus Pada PT. Pembangunan Perumahan 
(Persero) Tbk). Publikasi Ilmiah Akuntansi. Volume1, Nomor1. Universitas PGRI Adi Buana Surabaya.

Baridwan, Zaki. 2013. Sistem Informasi Akuntansi. Edisi Kedu. Yogyakarta: BPFE.

Dewi, Nyimas Vila. 2019. Faktor- Faktor Yang Mempengaruhi Profitabilitas Perbankan (Studi Kasus pada Bank Umum yang Terdaftar di Bursa Efek Indonesia Periode 2015 -2017). Journal of Chemical Information and Modeling. Volume 53, Nomor 9,P-ISSN:2541-6030, eISSN:2621-6957. Universitas Islam Malang.

Dwiarti, Rina. 2019. Evaluasi Faktor-Faktor Yang Mempengaruhi Profitabilitas Pada Perusahaan Manufaktur Yang Terdaftar Di Bei. Journal of Chemical Information and Modeling. Volume 53, Nomor 9. Universitas Mercu Buana Yogyakarta.

Effendi, Bahtiar. 2018. Profitabilitas, Solvabilitas dan Audit Delay Pada Perusahaan Consumer Goods Yang Terdaftar Di BEl. Riset \& Jurnal Akuntansi. Volume 2, Nomor 2, p-ISSN:25489224, e-ISSN:2548-7507. Matana University.

Harahap, Heri Faisal. 2020. Analisis Kinerja Keuangan Pemerintah Daerah Kabupaten Tapanuli Tengah. Ekonomis: Journal of Economics and Business. Volume 4, Nomor 1, ISSN:25976829. Universitas Batanghari Jambi.

Harmono. 2014. Manajemen Keuangan Berbasis Balanced Scorechard Pendekatan Teori. Jakarta: Bumi Aksara.

Kakasih, Gita Gabriella, Sifrid S. Pangemanan, dan Sherly Pinatik. 2019. Penerapan Sistem Akuntansi Penggajian (Studi Kasus Di Fakultas Ekonomi Dan Bisnis Universitas Sam Ratulangi). EMBA. Volume7, Nomor 3, ISSN: 2303-1174. Universitas Sam Ratulangi Manado.

Mulyadi. 2016. Sistem Akuntansi. Jakarta: Salemba Empat.

Munawir. 2012. Analisis Laporan Keuangan. Yogyakarta: Liberty.

Purba, Dimita H. P. 2018. Sistem Informasi Akuntansi Penggajian Dan Pengupahan: Studi Kasus Pada Sebuah Rumah Sakit. Jurnal Manajemen. Volume 4, Nomor 2,p-ISSN:2301-6256, eISSN:2615-1928. Universitas Methodist Indonesia.

Santoso, Arif Lukman dan Tekad Sukihanjani. 2012. Analisis Faktor-Faktor yang Mempengaruhi Likuiditas Perbankan di Indonesia. Jurnal Ekonomi Universitas Sebelas Maret. Universitas Sebelas Maret.

Saputri, Loli dan Yentina Siregar. 2019. Analysis Of Effectiveness And Efficiency Of Application Of Salary Accounting Information System At Pt. Cicor Panatec. BENING. Volume 6, Nomor 2, ISSN: 2252-52672. Universitas Riau Kepulauan.

Sugiono, Lisa P. dan Y. Christiawan. 2012. Analisa Faktor yang Mempengaruhi Likuiditas Pada Industri Ritel yang Terdaftar Pada Bursa Efek Indonesia Tahun 2007-2012. Business Accounting Review. Volume 1, Nomor 2. Universitas Kristen Petra.

Sujarweni, V. Wiratna. 2017. Analisis Laporan Keuangan Teori, Aplikasi, dan Hasil Penelitian. Yogyakarta: Pustaka Baru Press.

Watts, Ross L. dan Jerold L. Zimmerman. 1986. Positivie Accounting Theory. USA: Prentice-Hall. Yulianti, Eka Budi. 2018. Pengaruh Sistem Akuntansi Penggajian dan Pengupahan Terhadap Kepuasan Karyawan Pada PT. Tri Chemindo Ampuh. Jurnal Ekonomi. Volume 20, Nomor1. Universitas Tama Jagakarsa. 